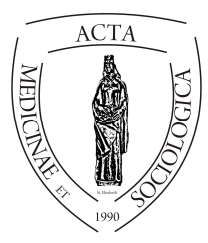

Acta Medicinae et

Sociologica (2019)

doi:

\title{
Nyíregyházi, telepi körülmények között élő, 18-29 éves roma fiatalok egészségmagatartása (fókuszcsoportos interjú)
}

\author{
Ember Zsolt
}

Phd hallgató, Semmelweis Egyetem Mentális Egészségtudományok Doktori Iskola. Budapest, VIII. Balassa u. 6.

\begin{tabular}{|c|c|}
\hline INFO & ABSTRACT \\
\hline $\begin{array}{l}\text { Ember Zsolt } \\
\text { zsolt.ember07@gmail.com }\end{array}$ & \multirow[b]{2}{*}{$\begin{array}{l}\text { Health behaviour of 18-29 year-old youngster living in } \\
\text { settlement conditions in Nyíregyháza (Focus group } \\
\text { interview) Besides being at economic, educational and } \\
\text { cultural disadvantage, Roma people prove to be a highly } \\
\text { disadvantageous social layer in health care, as well. The } \\
\text { most disadvantageous ones reside in settlements. Although } \\
\text { health is a basic value and activity potential for everybody, } \\
\text { it is unlikely to develop and function well without } \\
\text { sufficient knowledge on health and individual } \\
\text { responsibility, or when the right to access to health care } \\
\text { and the principle of equal treatment are damaged, or when } \\
\text { comprehensive social policy development programs are } \\
\text { incomplete, but most of all when the majority does not } \\
\text { show an inclusive attitude towards Roma people. The } \\
\text { present study reveals the health behaviour of young Roma } \\
\text { adults of 18-19 years of age through a focus group } \\
\text { interview. }\end{array}$} \\
\hline $\begin{array}{l}\text { Keywords } \\
\text { health, health behaviour, } \\
\text { Roma people, settlement } \\
\text { surroundings, focus } \\
\text { group interview }\end{array}$ & \\
\hline $\begin{array}{l}\text { Kulcs szavak } \\
\text { egészség, egészségmaga- } \\
\text { tartás, roma, telepi lakó- } \\
\text { környezet, fókuszcsopor- } \\
\text { tos interjú }\end{array}$ & $\begin{array}{l}\text { Absztrakt. A cigányság nem csupán gazdasági, oktatási és } \\
\text { kulturális hátrányok elszenvedője, hanem az egészség di- } \\
\text { menziójában is egy erősen hátrányos helyzetü réteget képez } \\
\text { - a leghátrányosabb helyzetben pedig a telepi lakókörnye- } \\
\text { zetben élők vannak. Az egészség alapvető értékként és cse- } \\
\text { lekvési potenciálként jelenik meg minden ember életében, } \\
\text { ami azonban nem tud megfelelően funkcionálni, ha hiá- } \\
\text { nyoznak a megfelelő szintü egészségismeretek, ha nincs } \\
\text { meg az egészségért vállalt egyéni felelősség, ha csorbul az } \\
\text { egészségügyi ellátáshoz való hozzáférés joga és sérül az } \\
\text { egyenlő bánásmód elve, továbbá, ha hiányosak a komplex } \\
\text { társadalompolitikai fejlesztő programok és nem utolsó sor- } \\
\text { ban, ha hiányzik a többségi lakosság inklúziós szemléletü } \\
\text { attitüdje a cigánysággal szemben. Jelen tanulmány a nyír- } \\
\text { egyházi, telepi körülmények között élő fiatal felnőtt (18-19 }\end{array}$ \\
\hline
\end{tabular}


éves) roma lakosok egészségmagatartását mutatja be, fókuszcsoportos interjú keretén belül.

Ez a tanulmány a TOP-6.9.1-16-NY1-2017-00001 azonosító számú

"Közösen a kiútért" című projekt támogatásával készült.

\section{Bevezetés}

A cigányság száma Európában 5-7 millió, ami Magyarországon 6-700 ezerre tehető - ez a lakosság 6-7\%-a (Kósa 2006:42). Ök képezik Magyarországon a legnagyobb etnikai csoportot, melynek a többségi populációhoz viszonyított egészségi állapota jelentősen kedvezőtlenebb (Forray 2013). Ennek fő okai részben rossz gazdaságitársadalmi helyzetükben és életmódjukban keresendő (Kósa 2006:45). Az egészséget és az életminőséget a környezeti, és a szociális-gazdasági tényezők egyaránt befolyásolják, melyekben halmozott hátrányok mutatkoznak a cigányság esetében, ezek pedig egészségegyenlőtlenségekhez vezetnek körükben (Hüse és Pénzes 2015:9). Wilkinson szerint a növekvő társadalmi távolság, vagyis a társadalmi egyenlőtlenségek okozzák leginkább a kisebbségek rossz megbetegedési és halálozási mutatóit rossz egészségi állapotuk tehát rossz szociális helyzetük eredménye (Forray 2013). A rosszabb egészségi állapotot meghatározó háttértényezők között a szegénység egy kulcstényező, mert az egészség terén megmutatkozó különbségek a társadalmi rétegződést követik - melynek pedig a forrásokhoz jutás és azok megőrzése, a társadalmi részvétel és a saját élet feletti kontroll, a munkahely, az iskolázottság, a jövedelem és a lakókörnyezet a legfőbb indikátorai (Hüse, Pénzes 2015:18). A romák esetében etnikai egészségi állapotról nem beszélhetünk, de az egészség-hátrányokat a kisebbségi helyzet magában hordja, amit a kirekesztődés, a rossz lakhatási körülmények, a negatív lakókörnyezet, az egészségügyi ellátáshoz való rosszabb hozzáférésük, a rossz mentális állapotuk és az alacsony szintü egészségtudásuk határoz meg és egy, az átlagpopulációhoz képest 10-15 évvel kevesebb várható átlagéletkorral jellemezhető kisebbségi csoportot eredményez (Hüse, Pénzes 2015:22; 78-79).

A cigányság körében végbemenő halálozási okokról számos pontos adat áll rendelkezésre, ám a megbetegedésekkel kapcsolatban nincsenek ilyen adatok (Forray, 2013). Kutatások alapján elmondható, hogy vannak a cigányságot jobban érintő betegségek, melyek a rossz lakásviszonyok, az elégtelen táplálkozás és a lakások túlzsúfoltsága miatt alakulnak ki (Forray, 2013). A cigányságot sújtó legfőbb betegségek és egészségkárosodások a mozgásszervi problémák, a pszichés eredetü megbetegedések (amit a társadalmi elszigeteltség tovább súlyosbít), valamint a szexualitással összefüggö népegészségügyi- és a fogászati problémák (Forray, 2013). Az életstílus és az egészség összefüggéseit vizsgálva kutatók azt állapították meg, hogy az egészségkárositó szokások gyakoribbak az aluliskolázottak körében, amit az alultápláltság tovább nagyít (Forray, 2013). 


\section{A magyarországi romák problémáiról}

Magyarországon a romák hátrányos helyzete kettős: egyrészt képzettségük hiánya, a nagycsaládos életforma és a társadalmi elöítéletesség miatt nem tudnak bekapcsolódni a társadalmi mobilitásba, másrészt pedig a hátrányos lakókörnyezetből kifolyólag, ami gettósodási folyamathoz vezet, így az elkülönülés mértéke tovább nő (Forray, 2013). Kérdés lehet, hogy vajon a roma kultúra, a roma kisebbségi csoporttagság határozza-e meg az egészségüket, egészségmagatartásukat, vagy inkább több dimenzió együttes kölcsönhatása (munka, jövedelem, iskolázottság, gazdasági helyzet, diszkrimináció, kirekesztettség) (Hüse, Pénzes 2015:14). A legújabb Európai Uniós programok szerint az egészség egyike a legfontosabb, a romák integrációjához hozzájáruló területeknek; ez az alapja ugyanis a magasabb szintü iskolázottságuknak és foglalkoztatottságuknak, amelyek a szegénységből való kitörés alapfeltételei - hiszen a rossz egészségi állapot generációkon keresztül is átöröklődik (Hüse és Pénzes, 2015:15-16).

Az egészségi egyenlötlenségben a romák között - országok közötti és országon belüli - területi különbségek is megfigyelhetök (Hüse, Pénzes 2015:14,16,17,25). A település típusától is függ, hogy hol milyen arányban élnek telepeken a romák: nagyobb városokban kevésbé jellemző ez a létforma (Solymosy, 2007). A telepeken élök rosszabb egészségi állapotban vannak, amit az elmaradott infrastrukturális szint is magyaráz és föleg a rossz szocioökonómiai státusz miatti alultápláltság, valamint éhezés is megfigyelhető náluk, ami főleg a gyerekek és nők körében vezet túlzott soványsághoz (Solymosy, 2007). Ezt alátámasztandó, a telepszerü körülmények közt élö romák gazdasági helyzetüket 40\%-ban nagyon rossznak ítélik meg, szemben az általános populációban mért 20\%-os aránnyal (Kósa, 2006:23). Az ő egészségi helyzetükkel csak kevés országos vagy reprezentatív kutatás foglalkozott eddig, pedig járványügyi szempontból leginkább a telepeken élő cigányok veszélyeztetettek (Forray, 2013).

A romáknak az egészségüggyel - és annak szereplőivel - is általánosan rossz a kapcsolatuk: az egészségügy iránti bizalom hiányzik, ami a kétoldali sztereotípiák, elóítéletek miatti elégtelen kommunikáció eredménye (pl. a veszélyeztetett terhességü kismama nem marad a kórházban orvosi kérésre sem) (Forray, 2013). Ennek részbeni oka a szexualitásban, szülésben, gyermekágyban fellelhető roma szokások, hiedelmek, melyek erős kulturális hatásként érvényesülnek és kerülnek szembe a szakmai ajánlásokkal, továbbá az egészségügyi dolgozók nincsenek felkészítve a szegényebb és iskolázatlanabb, főleg roma lakossággal való hatékony kommunikációra (Forray, 2013). Probléma az is, hogy a szegényebb cigányok csak akkor mennek orvoshoz, ha már nem viselik el a fájdalmakat - bár falun inkább felkeresik a háziorvost (a nők gyakrabban; véleményét tisztelik és elfogadják), ám a kórházi szakdolgozókkal az ottaniaknak is rossz a viszonyuk, ami félelemmel és előítélettel terhelt (Forray, 2013). A diszkrimináció gyakoriságát a kilenc ország részvételével készült EC Europa Eu jelentés is kiemeli, ami felnőtt romák egészségi állapotát, egészségmagatartását és az egészségügyi rendszerhez való viszonyukat vizsgálta (Forray, 2013). Kósa (2006) és munkatársai kutatásukban lakókörnyezeti-egészségügyi és demográfiai kutatást végzett három, romák által sürün lakott megyében (Szabolcs-Szatmár-Bereg, Hajdú, Borsod-Abaúj-Zemplén), mely 
kutatásban nagyobb lakósürüségü és rosszabb komfortfokozatú településrészeket definiáltak a szegény rétegek körében általánosan - akiknek azonban a többsége roma származású. A Kurt Levin Alapítvány vizsgálata az egészségügyi ellátáshoz való hozzáférés egyenlőtlenségét állapítja meg a romák körében, ami főleg vidéki és kistelepülési országrészeken sérül, mely területeken négy-öt falvanként van csak háziorvos, szürőlehetőségek és szakorvosi elérés pedig még ritkábban (Forray, 2013). Az utazás is drága, sokszor megoldhatatlan a romák számára, a védőnői körzetek pedig többnyire 300 föt is ellátnak, így nem jutnak el mindenkihez. Ez maga után vonja az ellátó rendszer reformjának szükségességét, főképp az ellátás megszervezésében (Forray, 2013). A romák alacsony szintü egészségügyi részvételét mutatja, hogy egyedül a nőgyógyászati szürés tekintetében nem maradnak el a roma nők az átlagpopulációtól ezt illetően, azonban más fontos, alapvető szürésben, mint pl. az emlőszürés és a rendszeres vérnyomásmérés, abban igen, amit ők az egészségügyi dolgozók diszkriminációjával magyaráznak (Kósa 2006:33-36). Az is statisztikai tény, hogy a romák szakellátásba való továbbküldése is alacsonyabb szintü az átlagtól (Kósa, 2006:45).

A rossz mentális egészség - mely kimondottan nagyarányú a kisebbségek, hazánkban a romák körében - szempontjából a családi jólét, a család gazdasági helyzete, szocioökonómiai státusza $(S E S)$ fontos prediktorok, melyeket ezért a kisebbségek esetében kiemelt fontosságúként kell kezelni. Ezen tényezők pszichológiai egészségre gyakorolt hatását vizsgálták Taylor és munkatársai (2012) 200, magas szintü pénzügyi nyomást átélő, afroamerikai kisebbségü család körében. A testi-lelki jóllétet befolyásolja a gazdasági nehézség és a szegénység, mely jelenség az USA-ban föleg az afroamerikaiak körében van jelen, a latin-amerikai lakosságtól is nagyobb mértékben, ahol az afroamerikai gyerekek egyharmada szegénységben él (Taylor, Budescu, Gebre 2012). A nők által vezetett háztartások majdnem 40\%-a ott leginkább szegény, és a munkanélküliség is a legmagasabb körükben: 12,3\%-os szintü. A nehézségek stresszorai - pl. hiányok - váltják ki a distresszt, az érzelmi distressz pedig házastársi- és családi konfliktusokat generál. Ezt tovább nehezíti, hogy az afroamerikaiaknak gyakran fajgyülölettel és diszkriminációval is szembe kell nézniük. Az eredmények szerint mindez az anyánál depresszív tünetekkel és a jövővel kapcsolatos optimizmus hiányával, valamint inadekvát szülői gyakorlattal, a serdülöknél pedig depresszív tünetekkel és probléma-viselkedéssel (externalizált és internalizált tünetek), valamint alacsonyabb szintü kompetenciákkal és rosszabb (főként pszichológiai) alkalmazkodással társult (Taylor, Budescu, Gebre, 2012).

\section{Anyag és módszer}

A 2019 tavaszán a nyíregyházi Huszártelepen zajló, életminőség-kutatással kapcsolatos fókuszcsoportos interjúsorozat jelen fejezete a Huszártelepen élő, 18-29 éves fiatalok egészségmagatartását, egészséghez füződő viszonyát igyekezett megragadni. Ez a romák között kiemelkedően fontos témakör a fókuszcsoportos interjú módszerével kitünően vizsgálható, hiszen a résztvevők kötetlenül és közvetlenül tudják gondolataikat, véleményüket, érzéseiket és tapasztalataikat kifejteni és megosztani, 
esetenként pedig megvitatni egymással. A 7 résztvevővel zajlott interjú - 1 férfi kivételével - egy- vagy többgyermekes anyukák jelenlétében zajlott, akik többnyire 10 éven aluli gyermekeket nevelnek. Iskolai végzettségüket tekintve a nyolc általános iskolai végzettség a gyakori közöttük, azonban 1 jelenlévő elvégzett 3 szakközépiskolai évet is, valamint ő és egy másik résztvevő rendelkezik érettségihez nem kötődő szakmával. Családi állapotukat tekintve mindannyian férjezettek, illetve élettársi kapcsolatban élnek. Foglalkozási státuszuk tekintetében fóállású anyák, férjeik dolgoznak, akik közül ketten Nyugat-Európában vállaltak munkát.

\section{Az interjú}

Fókuszcsoportomban a szinte kizárólagos női jelenlét azért is pozitívum, mert a roma nők egészsége az egész család szempontjából meghatározó, ugyanakkor ők többszörös társadalmi kirekesztettséget élnek meg (Hüse, Pénzes 2015:42) - ezért is fontos minél pontosabb képet kapnunk egészségmagatartásukról.

$\mathrm{Az}$ általam vezetett interjú oldott, nyílt légkörben folyt, senki sem érezte magát feszélyezettnek; amit el szerettek volna mondani a résztvevők, azt elmondták, ám a témától ezúttal is többször elkanyarodtak az őket foglalkoztató egyéb, aktuális gondjaik felé, melyek azonban valamilyen szinten és formában mégis csak kapcsolódtak az egészségmagatartás témaköréhez (pl. a közbiztonság és a szabadidős tevékenységek témája). Az elhangzottak alapján elmondható, hogy a Huszártelepen az egészségkockázati magatartások egész sora lelhető fel, melyek igen gyakoriak az ott lakók körében. A legnagyobb problémát az interjúalanyok szerint a kábitószerfogyasztás okozza, hiszen az erős függőséget okoz és számos „mellékhatással” jár együtt. A telepen számos díler van, akik az első adagokat ingyen adják, így alakítva ki a függőséget a főleg fiatal - és fiatalkorú - felhasználókban. Három fő drogfajtát neveztek meg az alanyok: a „fehéret” - kokaint -, a „füvet” és a „herbált”, aminek nagy része szárított patkányméreg, amit összesodornak és elszívnak (szintetikus kábítószer, melynek számos, szervezetre kiterjedt negatív hatása van). Ez utóbbi a többihez képest olcsóbb, ám rövidebb hatóidejű is: kb. 10-20 perc a hatása, és szó szerint „megbolondítja” az embert. A telepen 500 forintos darabáron árult „anyagból” elmondásuk szerint van, aki napi 10-et is elfogyaszt, és sok árusító a fogyasztók közül kerül ki, akik részesedést kapnak a befolyt összegből - ők csak így tudják fedezni saját fogyasztásukat. A „fehér” és a „fü” fogyasztása ritkább jelenség, mert drágább, ám erre is akad példa. Ezek hatása szerintük merőben más, mint a herbálé: inkább csak ,jókedvük" lesz tőle, elég hosszú ideig. Az egyik jelenlévő ezen kábítószerek rabja volt évekig, majd - saját bevallása szerint - pusztán a negatív hatású társaságból való kikerülésével sikerült leszoknia ezek használatáról. A kábítószert egyébként szerintük inkább a fiatalabb korosztály használja a telepen, de megfigyelhető idősebb, családos emberek körében is. A kábítószerezés a jelenlévőket azért is zavarja, mert az azt fogyasztó emberek a lakókörnyezeti biztonságot is fenyegetik: az utcán és az aluljáróban félájultan fekszenek, betörnek udvarokra, házakba, belekötnek a járókelőkbe és elveszik a gyerekek pénzét, esetleg meg is verik őket. Azonban telepen belül is más-más a helyzet, a biztonság eltérő mértékü az utcák között: nem 
minden utca egyformán veszélyes. Egy-két jelenlévőnek saját közvetlen tapasztalata is van erről: van, akinek pl. a testvérei, van, akinek a férje volt kábítószerhasználó. Ök függőségük következtében nem dolgoztak és függőségi kiadásaikat az otthonról lopott tárgyak eladásával biztosították maguk számára. A drogos ember családjának így igen nehéz élnie, hiszen racionális érvekkel nehéz hatni az ilyen, beteg emberre, akik ráadásul folyamatos családi figyelmet, monitorozást, ellenőrzést igényelnek, ami lassanként felőrli a család anyagi és humán erőforrásait egyaránt. A veszekedések, esetleges erőszakos cselekmények is mindennaposak az ilyen családokban, ráadásul vészhelyzet esetén a mentők gyakran csak rendőri kísérettel mernek kiszállni, és a betegek sokszor nem müködnek együtt: nem szállnak be a mentőbe és nem hagyják megvizsgálni sem magukat, vagy éppen az egészségügyi személyzet előtt élnek káros szenvedélyükkel. Az alanyok beszámolói szerint a pszichiátria, a drogelvonó sem segít, hiszen akár 2-3 hónap múlva is, ha kikerülnek onnan, újrakezdik, ha nincs elég akaratuk és motivációjuk ahhoz, hogy abbahagyják korábbi tevékenységüket - ez a résztvevők személyes tapasztalata. Az egyik résztvevő esetében, ahol a fiútestvérek drogoztak, ott a családi támogatás megvonása célt ért: a fiúnak el kellett költöznie otthonról és a saját lábán kellett megállnia, ami elég kényszerítő erő volt ahhoz, hogy abbahagyja a drogozást és munkába álljon, hiszen immáron egyedül kellett eltartania magát. Egy másik résztvevő férje, aki egyszer majdnem a karjai közt halt meg túladagolás miatt, a börtönben szokott le a szerről, ahol immáron 1,5 éve tartózkodik. Az elmondottak alapján 7-8 éve van jelen jelentős mértékben a kábítószer a telepen, és ha „le is kapcsolnak” egy-egy dílert, mindig van és lesz is, aki a helyébe lép. Ök maguk is ismerik azokat, akik árusítják a kábítószereket.

Az interjún a résztvevők a második legnagyobb problémaként az alkoholfogyasztást jelölték meg: szerintük az inkább az idősebb korosztályt érinti, bár előfordul az alkohol és a gyógyszer együttes fogyasztása is: sokszor vesznek be az emberek valamilyen nyugtatószert (Xanax, Frontin) és isznak rá aztán - akinek több pénze van, az whiskey-t, akinek kevesebb, az pedig „tablettás bort”. Sajnos mind a kábítószer-, mind az alkoholfogyasztás már igen fiatalon, akár 10 évesen is megjelenik a telepen, ami föleg a kevés szülői figyelmet kapó, magára hagyott, felügyelet, nevelés és kellő szigor nélkül élő, tengődő-elvesző gyerekek, fiatalok esetében figyelhető meg hiszen van olyan szülő, aki az iskolába járást sem kötelezi gyermekeinek, akik így, általában csapatokba verődve, éjszakának idején is az utcán vannak és tüzet rakva vészelik át a hideg estéket. Közülük sokan azt sem tudják sokszor, merre járnak a szüleik és gyakran énekelnek öngyilkosságról bánatukban, elkeseredésükben. Ezekkel a szülőkkel szemben az interjún jelen lévők egyöntetűen kifejezték ellenérzéseiket, és szerintük a megoldást a Gyámügy beavatkozása jelentené ezekben az esetekben, a gyerekek családból történő kiemelése által.

Dohányzás tekintetében általánosabb képet kaphatunk az interjún résztvevők szerint: szinte mindenki dohányzik a telepen (az interjúalanyok is, egy hölgy kivételével), bár vannak olyanok is, mint - az említett hölgy is ilyen volt - akiknek szülei és családtagjai egyaránt dohányoznak, ő maga azonban nem, és nem is szándékozik a jövőben sem. Sajnos a dohányzással kapcsolatban is megfigyelhető a már egészen kicsi gyerekek bevonódása is: a jelenlévők már 5 éves gyerekek körében is tapasztalták ezt a kockázati magatartást. Ennek legnagyobb prediktorát a családi dohányzásban látják: szerintük a szülők példája a legerősebb, legalábbis ami az első kipró- 
bálást érinti, aztán pedig már függők lesznek és így tovább dohányoznak. Ez a tapasztalat a nemzetközi kutatásokkal is egybevág. Tjora és munkatársai (2011) kutatásában családi szinten a proximális és a disztális hatások a serdülők dohányzásának megkezdése szempontjából egyaránt lényeges prediktorok: 13 és 18 év között a testvérek, szülők és barátok dohányzása szignifikáns mikroszintü prediktoroknak, a családi SES pedig makroszintü prediktornak bizonyult; a szülők és idősebb testvérek dohányzása erősen hatott a dohányzás elkezdésére és gyakoribbá válására egyaránt, a SES pedig direkt módon negatívan társult a megkezdéssel, és pozitívan a gyakoribbá válással. A szülői hatásnál erősebb volt az idősebb testvér hatása az elkezdésben, az alacsony SES pedig nagyobb esélyt jelent a korábbi dohányzás-elkezdésre bár a nemdohányzó család védőfaktor ebben. A kutatás szerint a két legerösebb prediktor az idösebb testvér és a legjobb barát dohányzása volt (Tjora, Hetland, mtsai. 2011). Shaefer és munkatársai (2012) vizsgálata szerint idővel hasonlóvá válik a serdülők dohányzása a barátokéhoz, akik a hasonló szinten dohányzók közül választják leginkább barátaikat. Megfigyelhető az is, hogy a dohányzáson kívül idővel egyéb viselkedés is a barátokéhoz lesz hasonló, amire részben magyarázat, hogy a hasonlóság alapján könnyebb számukra a kapcsolatot fenntartani és fejleszteni, ráadásul támogatják is egymást az ilyen típusú viselkedésben, vagy annak elkezdésében (Shaefer, Haas, Bishop 2012).

Arra a kérdésre, hogy mi lehet az oka a kockázati magatartásformák elkezdésének, az interjún részt vevők azt válaszolták, hogy a legfőbb okokat a stresszben, az idegi feszültségben és az anyagi-diszkriminativ nehézségekben látják. A droghasználatba való bevonódást - az említett személyes példa alapján is - föképp a baráti kör negatív hatásának (kortárshatások) tulajdonítják, ami szintén a kutatások adataival egybevágó tapasztalat, és amit - a többi egészségkockázati magatartással együtt szintén föleg serdülökorban kezdenek el a fiatalok. A hétvégi bulik szerintük még nem okoznának rászokást, de a galerik iskola utáni - vagy ahelyetti - mindennapos összejövetelein rendszeresen előkerülő drogok már komoly függőséget okoznak. Itt felmerül a szülői felelősség és monitorozás kérdése is, hiszen, ha ennek mértéke elég nagy volna, akkor szigorúbban vennék, hogy gyermekük hol, kivel és mikor jár. Az interjúalanyok szerint ők, mint anyukák nem engedik meg maguknak azt a fajta laza nevelési stílust, ami általánosnak mondható a telepen - ám lévén kisgyermekes anyukák, az igazi nehézségek majd akkor fognak jelentkezni, ha az ő gyermekeik is serdülökorúak lesznek.

A szerekről való leszokással kapcsolatban, mint támogató hatást elsősorban a társadalmi intézményeket (elvonó, pszichiátria, tanácsadó) jelölték meg a résztvevők, ám csak olyan szempontból, ahová fordulni lehet ilyen típusú problémák esetében - azok hatékonyságában ugyanis egyöntetüen nem hisznek. Szerintük kizárólag emberfüggő, hogy valaki visszaesik-e vagy sem; mint mondták, az egyén megítélésén és döntésén múlik, hogy továbbra is az ,álomvilágban” akar-e maradni, vagy „visszatér” a valóságba. A család támogató szerepét ők is elismerik, mert jobb, hogyha az ember mellett vannak rokonok, családtagok és nem pedig egyedül van, ám - a fentebb ismertetett nehézségek miatt - nem igazán akarják újra hazavinni őket, és szégyenérzetük is nagy miattuk mások előtt. Az interjúalanyok, elmondásuk szerint mindannyian rendelkeznek jól müködő baráti kapcsolatokkal (legalább egy baráttal) és a szomszédokkal is jó a viszonyuk, akikkel szintén meg tudnak beszélni 
bizonyos problémákat - a legbizalmasabb dolgaikat azonban inkább házastársukkal és szüleikkel beszélik meg. Így tehát, bár többnyire nem maradnak egyedül problémáikkal, a családot, rokonságot, szomszédságot és a baráti kapcsolatokat, bármily fontosnak is tartják, nem gondolják - az intézményekkel, drogtanácsadókkal egyetemben -, hogy preventív funkciót is betölthetnek - ami egybevág Gyukits György romák körében végzett interjú-kutatásának eredményével, miszerint jelentős részüknél megfigyelhető a prevenciós szemlélet hiánya (Forray, 2013). Ezen kívül nagyon ritka a roma családok körében az egészségtudatos nevelés, a gyerekekkel való beszélgetés, hiszen a szülök - többnyire alacsony iskolázottságuk miatt - maguk sem rendelkeznek megfelelő szintü, átadható egészségtudással és többnyire szintén nem egészségtudatosak.

$\mathrm{Az}$ interjún a következőkben felmerült, hogy a jelen lévők szerint a feszültség milyen alternatív levezetési módozatai (pl. sport) jöhetnének szóba a telepen élők számára. A sporttal kapcsolatban egyöntetüen állították, hogy az esetükben nem jöhet szóba, mivel egyrészt általában fáradtak, mint gyakorló anyukák (akiknek saját bevallásuk szerint az egésznapi rohangálás maga is egy sport), az apukák pedig fáradságos, esetenként külföldi munkával próbálják biztosítani családjuk megélhetését. Arra a kérdésre, hogy lenne-e haszna a telepen sportlétesitményeknek, esetleg egy konditeremnek, azt válaszolták, hogy azokat szerintük nem becsülnék meg az ott élők. Erre példaként hozták fel a jelenlévők, hogy a nemrég újonnan körbekerített futballpálya kerítését ellopták és a méhtelepen adták le, az új padokat pedig felszedték és eltüzelték. Az elektromos vezetékekből a rezet szintén eladják, a közvilágítást pedig rendszeresen tönkreteszik - csúzlival „kilövöldözik”. Ennek ellenére szerintük sportrendezvények szervezése népszerü lenne a telepen a fiatalok körében, akik jelenleg - lehetőségek híján - inkább csak fociznak; az idősebbek számára pedig kézmüves foglalkozásokat, gyöngyfüzést, társasjátékokat, ki-mit-tud-ok szervezését gondolják. Szerintük egyébként ezekről az igényekről a fiatalokat kellene megkérdezni - annak ellenére, hogy ők is azok -, mivel ők, családanyákként már nem „olyan” fiatalnak tartják magukat (ennek később némileg ellentmondtak: amikor a szórakozásról volt szó, magukat is „fiatalnak” tekintették). A kicsiknek föleg a tánctanítást jelölték meg, a cigány hagyományőrzés keretén belül. Elmondásuk szerint, ők, mint másként gondolkodó nők, ha el is járnának a telepen szervezendő szabadidős foglalkozásokra, hagyományosabb szemléletü nőtársaik „hülyének” néznék öket, és „,bolondnak”, ha még magukkal is szeretnék őket hívni. Szerintük ugyanis a többi anyukát nem érdekelnék ezek a lehetőségek.

Számitógép- és okostelefonhasználat tekintetében elmondták, hogy szinte mindannyian órákat töltenek „okostelefonozással”, de a számítógép-felhasználás inkább csak gyermekkorú rokonaik körében gyakori - ami főleg a multimédiás játékokra korlátozódik. A játékszoftverek náluk már szinte függőséget okoznak: egyikük rokona például szinte őrjöng és rombol, ha a játékban veszít, egy másik résztvevő rokona pedig még evés és tisztálkodás idejére sem akarja abbahagyni a játékot. Ök azonban figyelnek gyerekeik számítógép-használatára, többségük gyermekei pl. csak az iskolában játszhat. Az interjúalanyok maguk is naponta órákat telefonoznak, facebook-oznak, híreket olvasnak, de csak a gyerek mellett, pihenésképpen, és nem összefüggő időintervallumokban, így ezt az időt, saját bevallásuk szerint - és kérdésemre reagálva - nem is tudnák sportra fordítani, mert ahhoz már eleve fáradtak 
lennének. Szerintük nem csak a gyerekeknek, hanem manapság mindenkinek lételeme már az okostelefon, de föleg a fiataloknak az, így körükben sem lenne a sport telefonozást és számítógépezést helyettesítő elfoglaltság.

A saját egészségre vonatkozó felelösségvállalás kapcsán elmondták, hogy a telepen élő roma embereket egyáltalán nem érdekli az egészségi állapotuk, általában - a kutatásokkal egybehangzóan - csak akkor fordulnak orvoshoz is, ha már nagy a baj. És bár a jelenlévők számára, elmondásuk szerint, fontos az egészségük, ez értékként jelenik meg számukra, és azt is úgy gondolják, hogy az ember sokat tehet az egészségéért - ezt is „,csak akarni kell”, mint minden mást -; mégis úgy vallják, hogy ők is csak akkor hagynának abba egy-egy egészségkockázati magatartást - pl. tennék le a cigit -, ha valamilyen nagyobb bajuk derülne ki ezzel kapcsolatban - az egészségtudatosság tehát inkább elvi kérdés náluk és nem gyakorlati.

$\mathrm{Az}$ egészségtudatos étkezéssel kapcsolatban az interjú alanyai elmondták, hogy egyrészt idejük sincs tudatosan főzni, másrészt pedig ők ,azt eszik, amit megkívánnak, amit szeretnek". Az interjún részt vevők igyekeznek férjük és gyerekeik kívánsága szerint fözni, de a tápanyag-, vitamin- és zsírtartalomra egyáltalán nem figyelnek oda. A gyerekek mellett egyébként sincs idejük sokat fözni, „,esznek, amit tudnak”, ám van, aki figyel a gyümölcsbevitelre is és van, aki vitaminokat is szed.

Azzal kapcsolatban, hogy miben látnák a megoldást az interjúalanyok az egészség, a tisztább és biztonságosabb lakókörnyezet megteremtésére, két véleménycsoport alakult ki. Az egyik csoport szerint az egészségügyi ellátórendszer és a rendöri jelenlét erősítése, fokozása, bővítése lenne a megoldás: közelebbi védőnői és orvosi ügyelet, valamint posta a telepen. A jelenleg járőröző polgárőrök munkája szerintük nem ér semmit, mivel általában ők is cigányok és a többiek nem hallgatnak rájuk, valamint ők nem tesznek semmit, csak „,végigvonulnak”. „Nem kapnak pénzt, önkéntesek többnyire, de nem is tesznek semmit" - mondják. A rendszeresebb és nagyobb létszámú rendőri jelenlét - valamint a jelenleg üresen álló és szerintük csak mutatóba épült rendőrőrs „beüzemelése” - szerintük sok problémát megoldana: kevesebb drogos, díler és strici lenne a telepen, javulna a közbiztonság és kevesebb lenne a kábítószerfüggő is - máshonnan pedig nem mernének idejönni idegen dílerek. Azok, akik velük nem értenek egyet, a másik csoport, ők arra hivatkoznak, hogy ha minden szolgáltatás ténylegesen ennyire helyben lenne, akkor még jobban elszigetelödnének a többségi társadalomtól, és még kisebb esélyük lenne az integrációra, mint így, ráadásul a diszkrimináció is nagyobb mértékü lenne velük szemben. Szerintük inkább fel kellene számolni a telepet és annak lakosait a többségi lakosok között elvegyíteni, szétszórni őket a városban - így a javuló életfeltételekkel egészségük és egészségmagatartásuk is javulna. Ám erre is akadt ellenkezés, mégpedig egyrészt az, hogy van, aki szerint számos itt élő ember szemetelö életmódját nem tolerálnák a városlakók és ott is sokan csak pusztítanának és eladnának, amit lehet, másrészt pedig sokan, mivel ott születtek (a telepen), nem is kívánnák elhagyni azt a környezetet, ahol jelenleg élnek. Ök inkább abban látnák a megoldást, ha szép szóval, elmagyarázva, példát statuálva mutatnának egy jobb utat az adekvátabb létezésre telepi társaiknak, saját példájuk által szemléltetve, hogy lehet másképpen, lehet jobban is csinálni, „emberibben” is élni. Erre azonban szintén volt, aki azt mondta, hogy ez szinte lehetetlen, mert az ott élő emberek még abban sem hagyják, hogy mások beleszóljanak az életükbe, hogy a zenét mikor és milyen hangerőn hallgatják 
- vagyis autonómiájukból nem engednek, és többségük kompromisszumokra is képtelen. Így viszont valóban lehetetlen lenne a városiakkal való közös lét. Élnek azonban a telepen hozzájuk hasonlóan másként, jobban, nyitottabban gondolkodó emberek is szerintük, akikkel azért csak szót lehetne érteni, hiszen, ahogyan a magyaroknál sem, úgy a cigányoknál sem lehet mindenkit egy kalap alá venni, és mivel nem csak a negatív, hanem a pozitív példa is „ragadós”, így van esély a változásra, a változtatásra.

A régi, elavult cigány hagyományokkal kapcsolatban az interjún szóba került a túl fiatalon való szülés is, ami a telepen szintén jelen lévő, részben az egészségmagatartáshoz, részben kulturális hatásokhoz kapcsolható probléma: a telepen is van olyan fiatal lány, inkább gyermek, aki 14 évesen már a második gyermekét várja az elsőt 12 évesen szülte. Mint mondják, olyan is akad, aki már 10 évesen összeköltözik a „párjával”. Azonban már a telepi körülmények között élök közül is egyre többen ítélik el ezt a dolgot és támogatják a minél későbbi, lehetőleg szakma megszerzése utáni első szülést. Az egyik jelenlévő lány, aki 18 évesen szült, még így is megjegyezte, hogy volt, aki még őt is elítélte a „túl korai” szülés miatt.

Az interjú egyik sarkalatos pontja volt az egyre inkább lepusztuló telepi lakókörnyezet fizikális állapota is, mint egészségre igen káros külső hatás: legtöbben emiatt és a zajos szomszédok miatt költöznének el leginkább - nyaranta ugyanis szerintük leginkább egy „non-stop utcabálhoz” hasonlít a telep, szünet nélküli mulatozással és zenehallgatással. A lakások tekintetében elmondták, hogy általánosságban hidegek, nedvesek, a néhol újonnan berakott müanyag nyílászárók ellenére is, hiszen a szigetelés hiánya miatt télen szinte füthetetlenek a házak, nemegyszer kell napközben nagykabátban mosogatni és aludni esténként. A házak falai omladoznak, a nedvesség miatt rendszeres a penészesedés. A sok, házaknál lévő „szemétdomb” miatt elszaporodtak a patkányok és az egerek, amik az egyébként tisztán tartott lakásokba is bemennek és ott tovább szaporodnak. A hideg házak miatt sokszor a gyerekek is megfáznak, és a hideg, a nyirkosság a telepen egyébként is rossz egészségi állapotban lévő idősek egészségének sem kedvez.

Nem minden, interjún jelenlévőt érdekel azonban a telep sorsa, mint elhangzott, és az sem, hogy mi történik ott: van, aki kézzel-lábbal menekülne, költözne onnan, „5 perc alatt összepakolna és elmenne, ha tudna" - ám abból a pénzböl, amiből a telepen megél a családjával, abból a városban még az albérletet sem tudná fizetni. Falura, tanyára azonban egyikük sem költözne, mert egyrészt nem szeretnének állatokkal foglalkozni, másrészt pedig szerintük túl unalmas a falusi létforma - akkor már inkább ott maradnak, ahol vannak, mert ott legalább - kissé ellentmondóan az imént vázolt panaszokkal - ,zajlik az élet”. Már azonban a lakhely, a lakcím is elöítélet forrása, pl. munkakereséskor: amint meglátják, hogy hol laknak, azonnal elutasítják kérelmüket, még ha másban meg is felelnének a kritériumoknak. Ezért az interjúalanyok többsége egyrészt megérti a megélhetési bünözést folytatókat, másrészt pedig elítéli őket, hiszen ilyen feltételekkel, aki akar és minden szükséges változtatást meg is tesz - önmagán, környezetén és életmódján -, az sem tud kilépni ebből a megbélyegzésből, szegregációból és a szegénység ördögi köréből. Mindezen nehézségek ellenére saját részről egyikük sem számolt be informális munkavégzésröl. Összességében, bár sok minden változott szerintük a telepen az utóbbi időben - pl. új 
utak létesültek, javultak a lakhatási feltételek -, még mindig vannak változatlanul elmaradt és igen nagy mértékben lepusztult környékek, utcák.

Az interjú vége felé szóba kerültek a felvilágositó programok, ám az interjúalanyok szerint ezek sem érdekelnék az ott élő embereket, hiszen saját egészségük sem érdekli őket; rendezvényekre is csak akkor mennek el legtöbbször, ha valamit, föleg pénzt „osztanak”. Az ott lakók többsége szerintük mindenre képes lenne, hogy pénzhez jusson. Probléma továbbá, hogy a szülők szerint a gyerekeket is sok diszkrimináció éri az iskolában, és maguk is tapasztaltak már ilyet életük során; pl. az egyiküket - jó tanulmányi eredményei ellenére sem - engedték tanárai a helyi egészségügyi szakközépiskolába jelentkezni. Ez a típusú diszkriminatív jelenség elsődlegesen az érintettek mentális egészségére és jóllétére van káros hatással és emellett a társadalmi mobilitást is akadályozza.

Az interjú összegzéseként elmondható, hogy kevésbé bizakodók voltak a résztvevők, akik a változást, fejlődést akarók képviselői is egyben, hiszen a többség szerintük nem akar változást és nem akar változni sem - ezen pedig szerintük az intézmények és társadalmi törekvések sem segíthetnek. A többségnek ,jó úgy, ahogy van”, ha pénzt kapnak, „elvásárolják, elkártyázzák, elverik, elmulatozzák, aztán meg lesz, ami lesz". Szerintük a telepet fel kellene számolni, mert egymás példája viszi őket bele leginkább ebbe a folyamatba és felfogásba: „amíg csak egymást látják” nem fog változni semmi (a telepi romák 76,1 \%-a kizárólag cigányokkal él együtt; Solymosy, 2007). Már a fele telepi lakosság viszont szerintük úgy él, „,ahogy kell”. Gettónak tartják azonban a telepet, ahonnan elgondolásuk alapján szándékosan „nem akarják kiengedni őket”, amiről azok tehetnek, akik nem akarnak változni. „Muszájságból” vannak tehát ott, ahonnan szerintük nem fognak soha „kijutni”. A városban azonban, úgy vélik, jobb életkörülményeik lennének, így változtatni is jobban tudnának.

\section{A roma és nem roma fiatalok egészségmagatartása a hazai kutatások tükrében}

A sikeres prevenciós programok tervezéséhez fontos ismernünk a többségi és a roma fiatalok egészségkockázati magatartásának főbb jellemzőit. A többségi társadalom egészségmagatartásával a Magyar Ifjúság Kutatás 2016 ad átfogó képet, reprezentatív eredményeket, míg a telepeken élő romák egészségével, egészségkoczkázati tényezőivel kapcsolatban Kósa Zsigmond 2006-os disszertációja, Hüse Lajos és Pénzes Mariann 2015-ös kutatása, valamint Solymosy József Bonifácz 2007-es tanulmánya szolgálnak igen fontos adatokkal.

A fiatalok körében a kábítószerfogyasztással kapcsolatban a Magyar Ifjúság Kutatás 2016 is elég aggasztó képet mutat: a magyarországi 18-29 évesek 40\%-a ismer olyan embert, aki próbált már ki valamilyen kábítószert. Ez leginkább a 20-24 éves korosztályra és a megyeszékhelyeken ill. városokban élőkre jellemző, legkevésbé pedig a 15-19 évesekre és budapesti lakosokra. Ezen kívül a fiúk körében ez 10\%-kal magasabb arányban jelenik meg, mint a lányok között. A megkérdezettek harmada továbbá könnyen tudna kábítószerhez jutni, ha akarna (Magyar Ifjúság Kutatás, 2016). 
Az alkoholfogyasztás a többségi társadalomban is igen magas. Szintén a Magyar Ifjúság Kutatás 2016 eredményei szerint a 18-29 évesek 27\%-a szinte soha, 11\%-a heti rendszerességgel, 1\%-a pedig naponta fogyaszt alkoholtartalmú italokat. A havonta vagy ritkábban fogyasztók aránya az elmúlt négy év során növekedett. A lányok 60\%-a, a fiúk 40\%-a ritkán vagy soha nem fogyaszt alkoholt, míg a 15-19 évesek 20\%-a, a 20-29 évesek 35\%-a havi rendszerességgel fogyaszt (Magyar Ifjúság Kutatás, 2016). Kósa (2006) kutatásában a telepeken élő nők nagyobb mértékben absztinensek (83\% szemben az általános populáció 57\%-ával), a 18-29 éves férfiak pedig inkább nagyivók (telepeken 16\%, általános populációban 12\%) (Kósa, 2006:28-29).

Dohányzás tekintetében a Magyar Ifjúság Kutatás 2016 eredményei szerint a 15-19 éves korosztály13\%-a naponta, 67\%-a pedig abszolút nem dohányzik, míg a 20-29 évesek $29 \%$-a napi szinten, $52 \%$-a pedig soha. Nemi bontás alapján a lányok $17 \%$-a naponta, 65\%-a soha, míg a fiúk 31\%-a naponta, 48\%-a soha nem dohányzik. Iskolai végzettség szerint a magas iskolai végzettségüek 17\%-a, a középfokú végzettségüek $20 \%$-a, az alacsony iskolai végzettségüek 30\%-a dohányzik rendszeresen, míg a felsőfokú végzettségüek 66\%-a, az alacsony végzettségüek 53\%-a soha (Magyar Ifjúság Kutatás, 2016). Láthatjuk tehát, hogy az alacsony iskolai végzettség rizikófaktor a rendszeres dohányzásban, amit a telepi körülmények tovább rontanak: az általános populációhoz viszonyítva háromszoros az alacsony iskolai végzettségüek aránya a telepszerü körülmények között élök körében (Kósa, 2006:20). Kósa (2006) kutatása szerint Magyarországon ma igen magas a napi rendszerességgel dohányzók aránya (az ifjú korosztályt is beleértve) a teljes populáción belül is és a dohányzással összefüggő halálokok aránya szintén. A többségi populációt a telepeken élökkel összehasonlítva a rendszeres dohányzás (több, mint napi egy doboz) a 18-29 éves korosztályt vizsgálva a telepeken élö nők körében 25\%-os, a férfiaknál 50\%-os, míg az általános populációban ugyanez az arány a nőknél 12\%, férfiaknál 23\%, az érintettséget tekintve. A helyzetet súlyosbítja, hogy a dohányzás kezdete igen fiatal korra tehető a telepeken belül (Kósa, 2006:28), amit az interjúalanyok is alátámasztottak.

A felelősség kérdése Kósa (2006) kutatásában is szerepelt: a „Mennyit tehet az egészségéért?" - kérdésre kapott válaszok alapján a 18-29 évesek körében az általános populáció $90 \%$-a szerint az egyén sokat, vagy nagyon sokat tehet, míg a telepszerü körülmények között élőknek ezt csak alig 70\%-a vallotta (Kósa, 2006:26). Kutatásában is megjelent, hogy a telepeken élö romák, bár sokszor tudnak is egyegy egészségkockázati magatartás káros hatásáról - interjúalanyaimhoz hasonlóan -, mégsem mondanak le róla (Kósa, 2006:44). Az egészségi állapot megőrzéséhez azonban nem elég a társadalmi felelősségvállalás és a társadalmi feltételek megteremtése, hanem ugyanolyan fontos az egyéni felelösségvállalás is ebben a folyamatban (Kósa, 2006:44); ez a folyamat ugyanis egyszerre egyéni és társadalmi is, melyben a részfolyamatok kiegészítik egymást és egyúttal egymásra is épülnek.

Kósa (2006) kutatásában az egészséges táplálkozással összefüggésben a növényi olaj használatát és a zöldség-gyümölcs fogyasztásának gyakoriságát mérték. Ennek alapján a növényi olaj használata a telepi körülmények között élők körében $1 / 4$ részben jelent meg, szemben az általános populáció 2/3-os arányával, míg a kérdezést megelőző egy hónapban történt zöldségfogyasztást illetően a telepeken élők 30\%-a, az általános populáció 50\%-a fogyasztott ilyen típusú ételt. Elmondható az is, hogy a 
kor előrehaladtával inkább a telepeken élő nők híznak el, míg fiatal korukban inkább a túlzott soványság jellemző rájuk, a telepi férfiak körében pedig a fiatalkori elhízás a gyakoribb (Kósa, 2006:29). Sokszor fordul elő az is, hogy a romák számára oly fontos húst és édességet nem tudják megvenni a telepeken élők, mert drága (Forray, 2013). A táplálkozás és az egészségkockázati magatartások összefüggésével kapcsolatban elmondható, hogy a szakirodalom szerint az alultápláltság, a vitamin- és tápanyaghiányos étrend erősítő hatással van a rizikómagatartásokra (Forray, 2013).

A lakókörnyezettel való elégedettség terén Kósa (2006) kutatása azt mutatja, hogy a telepeken élők rendszerint elégedetlenek azzal a környékkel, ahol élnek, amely jelenség a fiatal nők körében gyakoribb (Kósa, 2006:24) - és ami összhangban van az interjú fiatal női alanyainak véleményével. Solymosy tanulmánya szerint a telepeken élők 76,1\%-a Magyarországon saját házban él, 15,5\% béreltben, fóleg önkormányzatiban és elmondható, hogy telepeken föleg saját lakással rendelkeznek a romák (Solymosy, 2007). A telepi lakosok 33,9\%-a egyszobás, 33,2\%-uk kétszobás lakásban él, 3,5\% egyhelyiséges házban, egynegyede háromszobásban - a telepeken továbbá nagyon kevés a fürdőszobával is rendelkező ház $(41,4 \%)$ (Solymosy, 2007). Az egyszobás lakások elterjedtségét állapította meg Kósa (2006) kutatása is, aki szerint a magas fokú gazdasági inaktivitás miatt is rosszabbak a lakáskörülmények (Kósa, 2006:24).

\section{Iskolai végzettség és foglalkoztatottság a romák körében}

Az iskolai végzettség emelése a romák körében gazdasági-kulturális kulcskérdés, hiszen az iskolázottsági szint emelkedésével jobb munkaerő-piaci pozícióhoz és ezáltal több jövedelemhez juthatnak (Hüse, Pénzes, 2015:80). Kósa (2006) szerint a 18-29 évesek korosztályában a csak alapfokú iskolai végzettséggel a telepen élő romák 73\%a rendelkezik, szemben az általános populáció 16\%-ával, ám ezen telepi lakosok közül csak 17\% az aktív dolgozó, szemben az általános populáció hasonló korosztályával, melynek 62\%-a dolgozik (Kósa, 2006:22). Itt persze számos magyarázó ok lehet, mint pl. a magas gyermekszám (ami szinte munkaidős anyaságot kíván), a klasszikus, cigány női szerepek (a gyereknevelést és a háztartás vezetését várják el tőlük főleg a cigány férfiak), valamint a stigmatizált diszkrimináció és a lakóhely szerinti negatív megítélés és elutasitás - melynek példája az interjúban is megjelent. Itt meg kell említenünk, hogy a diszfunkciós otthoni és oktatási környezet, a családi értékrend és a szegénység a fó, tanulást hátráltató okok - a cigány gyerekek iskolai lemaradása tehát nem etnikai sajátosság (Hüse, Pénzes, 2015:20,21). A tanári sztereotípia, a nemre, etnikumra irányuló diszkrimináció egyaránt káros hatású mind az egyénre, mind az osztálytermi közösségre nézve, hiszen az osztály hangulata egységes szokott lenni (Eccles, Roeser, 2011). Ha tanári diszkriminációt élnek át a diákok, az pszichés distresszhez vezethet náluk. Így hát az osztályterem érzelmi klímája is fontos és a tanár-diák kapcsolat is, melyek a tanulási motivációra és a serdülők szociálisemocionális jóllétére szintén hatással vannak (Eccles, Roeser 2011). 
A hátrányos helyzetű tanulók szegregációja felgyorsult az elmúlt években, ami érinti az oktatási rendszert is, annak ellenére, hogy számos, ez ellen irányuló intézkedéseket hoztak az utóbbi időben (2019. évi országjelentés - Magyarország). Ez maga után vonja a romák - a megfelelő alapkészségek elsajátításának hiánya miatti - magasabb szintű képzések felé való elmozdulásának, s ezáltal a társadalmi mobilitási esélyének nagymértékü csökkenését - ráadásul a korai iskolaelhagyók is a cigány etnikumból kerülnek ki túlnyomórészt (65,3\%) (2019. évi országjelentés - Magyarország). Ennek is következménye, hogy a munkaerőpiacon jelen lévő, alacsony iskolai végzettségü munkavállalók esetében a romák négyötöde legfeljebb 8 általános iskolai végzettséggel rendelkezik, míg ez az arány a nem romáknál csupán egyötöd (Munkaerőpiaci helyzetkép, 2014-2018, KSH). Pozitívum, hogy a roma nők közül is egyre többen végzik el az általános iskolát, ám tovább nőtt a többségi társadalom iskolai végzettségi szintje is és így a szakadék szintén, köztük és a romák között e téren - azonban az iskolázottságnak nem csak a foglalkoztatásban, és így az életfeltételek javulásában van nagy szerepe, hanem a gyermeklétszámban, valamint a kulturális- és egészségmagatartásban is (Forray, 2013).

A romák, mint kiszolgáltatott társadalmi csoport munkaerőpiaci eredményei a mai napig gyengék: többnyire alacsony foglalkoztatási ráta és az általános populációhoz képest alacsonyabb bérezés jellemző körükben (2019. évi országjelentés - Magyarország). Bár a romák foglalkoztatottsága 2014 és 2017 között 33\%-ról 45\%-ra növekedett, ám közülük 36,6\% közmunkaprogramban vesz részt (2019. évi országjelentés - Magyarország). Ez főleg az utóbbi időben megnövekedett munkaerö-keresletnek köszönhető és nagyban segítette a romák munkaerőpiaci beilleszkedését, valamint elmondható, hogy körükben 2016-tól nőtt az elsődleges munkaerőpiacon elhelyezkedni tudók aránya is (Munkaerőpiaci helyzetkép, 2014-2018, KSH). Általános jelenség továbbá, hogy a kis- és sokgyermekes anyákat alacsony szintü gazdasági aktivitás jellemzi (Hüse, Pénzes 2015:43), amit a roma tradíciók csak tovább erősítenek (Munkaerőpiaci helyzetkép, 2014-2018, KSH). Bár a roma nők már kevesebb gyermeket hoznak világra, mint néhány évtizeddel ezelőtt (Forray, 2013), a roma nőknek még mindig csak 36\%-a dolgozik fizetett munkahelyen (2019. évi országjelentés - Magyarország). A romákkal kapcsolatos munkaerőpiaci intézkedések - hasonlóan más hátrányos helyzetü csoportokhoz - még mindig nem elég támogatók, a szociális és egészségügyi szegmensekkel való koordinációjuk mértéke nem kielégítő, ugyanakkor ezen tényezők a lemaradó rétegek sikeres integrációjának fontos részét képeznék (2019. évi országjelentés - Magyarország).

\section{Társas támogatás és egészségmagatartás}

A társas támogatás jelentőségét a szakirodalom az interjúalanyoknál sokkal fontosabbnak tartja, hiszen az alapvetően nem más, mint azon emberek elérhetösége, akikre az emberek számítani tudnak (Sivandani, Koohbanani, Vahidi, 2013). A társas támogatás alacsony szintje fizikális és mentális szinten egyaránt szegényes egészségkövetkezményekkel jár együtt (Sivanandi, Koohbanani, Vahidi, 2013), a túl sok és túl kevés támogatás továbbá egyaránt káros lehet és externalizált tüneteket 
okozhat, ami rizikófaktor a fiatalkori bünözéshez és az erőszakos viselkedéshez szintén (White, Renk, 2012). Ezen tényezők ugyancsak kiemelt jelentőségüek a telepi környezetben élő fiatalok körében. A szociális támogatás alapvetően megakadályozhat rendellenes-, és elősegíthet pozitív fejlődést (Bockhorst, Sumter, Westenberg, 2010). Ez különösen fontos az etnikai kisebbségek számára, amit nemzetközi kutatások is igazolnak. Taylor és munkatársai (2012) már említett kvalitatív kutatásában az afroamerikai családok körében a rokoni támogatás pozitív hatásúnak bizonyult, társult viszonyban volt a családok nehéz anyagi helyzetével és pénzügyi nyomásával. A kutatásban a rokoni támogatás az anyák depresszív tüneteire nem volt hatással, de a jövőre vonatkozó optimizmusukra pozitívan hatott, míg a támogatás szegényes formája nem javított az anya pszichés jóllétén. Mind a serdülőknél, mind az anyáknál kimutatható volt ugyanakkor az alacsonyabb distressz, ha érzelmileg és szociálisan is számíthattak a rokonok támogatására. A rokoni támogatás tehát egy védőfaktor, ami a családi funkcionalitást összességében segíti, valamint hozzájárul a jobb kulturális és szociális adaptációhoz is (Taylor, Budescu, Gebre, 2012).

Az utóbbi időben a kutatások fókuszát illetően a társadalmi rizikók előtérbe kerültek az egyénivel szemben: az egyéni védőfaktorok mellett megjelentek a társadalmi mintázatok, struktúrák, és a kultúra egészség-formáló hatásainak vizsgálatai is, amiben a családi tényezők közül a struktúra, a jövedelem és az etnicitás számítanak a leginkább (Viner, és mtsai, 2012). Az interjún részt vevők elítélik a nevelés hiányát, elmondásuk alapján ők ebben már tudatosabbak, mint a telepen élö többség. Ez azért is fontos, mert a jó családi kapcsolódás késlelteti a szexuális élet elkezdését, a szerhasználat alacsonyabb szintjét eredményezi, és általa kevésbé valószínü, hogy erőszakos viselkedésbe keverednek a serdülők (Viner, és mtsai, 2012). Azok a szülők, akik tudnak gyerekeik tevékenységeiről, általánosságban mérséklő hatással vannak azok probléma-viselkedésére, amit a családi normák szintén befolyásolnak. A szülők viselkedése közvetlenül hat a serdülők egészségére és viselkedésére, a kulturális és etnikai különbségek pedig negatívan hatnak az iskolai eredményességre (Viner, mtsai, 2012).

\section{Zárszó}

A romák kirekesztettsége és egészségi állapotának, egészségmagatartásának fejlesztése csak minél több roma értelmiség képzésével lenne megoldható. A 2011-ben alakult KRSZH (Keresztény Roma Szakkollégiumi Hálózat) pont ezt a célt szolgálja, melynek egyik végcélja, hogy a végzett hallgatók cigány identitásuk vállalása mellett, keresztény értékek mentén, egyfajta híd szerepet töltsenek be a többségi populáció és a roma társadalom között - közéleti, közösségfejlesztő feladatok vállalásával és felelős, aktív társadalmi párbeszéd kialakításával (Dávid, Szabó, Lukács 2017). Kérdés azonban, hogy van-e visszatérés számukra a kibocsátó cigány közösségekbe, várja-e, visszafogadja-e őket egykori lakóhelyük (Dávid, Szabó, Lukács 2017). Ezen kívül szinte szó szerint „két tüz közé” kerül ez a réteg a kibocsátó közeg és az új társadalmi közeg között: a többségi réteg a diszkrimináció és a kulturális eltérések miatt fogadja be nehezen őket, a másik oldal számára pedig a visszafoga- 
dás megy nehezen. Az egyetemen a roma tanulók egyszerre élnek meg kultúraütközést és identitásválságot, asszimilációs törekvéseiket pedig a diszkriminációs hatások zavarják - továbbra is fontosak maradnak azonban számukra a családi és rokoni kötődések, mint melegséget adó, támogató szociális kapcsolatok (Forray 2013). Dávid és munkatársai (2017) KRSZH-s tanulmányának életinterjúiból is kiderül, hogy a felvételt nyert hallgatók családjai - bár szüleik többnyire alacsony szintü iskolai végzettséggel rendelkeznek - mindig is támogatták, bátoritották gyermeküket tanulmányaik folytatásában (sokkal inkább mentálisan és érzelmileg, mint anyagilag és szellemileg) és a tanulást értékként értelmezték. A tanárok, oktatók, mentorok részéről a tanulmányi előmenetelük folyamatában általánosságban szintén sok segítséget kaptak az iskolákban, ám akadt példa tanári és osztálytársi diszkriminációra is (Dávid, Szabó, Lukács 2017). A cigány értelmiségi rétegnek mindenesetre nagyon nehéz megöriznie belső egyensúlyát, ehhez az egyéneknek énhatékonyságukat és rezilienciájukat egyaránt erősíteniük kell (Dávid, Szabó, Lukács 2017). Ez azért is fontos, mert a cigány értelmiségi réteg mentális állapotára vonatkozó kutatások szerint mentális státuszuk nem jó, mentális problémáik a többségi értelmiségi réteghez képest súlyosabbak és gyakran fedezhetö fel náluk megfelelési kényszer, düh, túlkompenzálási törekvés és csalódottság (Forray, 2013).

A jövőre vonatkozó legfontosabb intézkedéseknek a romák egészségi állapotának és egészségmagatartásának javítására kell irányulnia a következők megvalósítása révén: közös, nem elkülönülő programok keretén belül az alapellátást elérhetővé kell tenni az egész lakosság, a romák számára is; az egészségügyi dolgozók romákkal való kommunikációját fejleszteni kell; a cigányságról szóló ismereteket be kell vezetni az egészségügyi képzésbe; a roma egészségügyi dolgozók számát növelni kell, valamint a durva egészségügyi bánásmódokat vissza kell szorítani (Forray, 2013). Ezen kívül egyéb területeken is emelni kell a romák foglalkoztatottságát, erősíteni társadalmi részvételüket, a szürö-gondozó szolgáltatásokat ki kell bővíteni és meg kell kezdeni a telepek rehabilitációját vagy felszámolását (Kósa, 2006:42). Ezen célok elérése érdekében a rendszeres egészségfelmérések a továbbiakban is kiemelten fontosak a komplex, interszektoriális programok tervezéséhez (Kósa, 2006:45).

\section{Felhasznált irodalom}

1. Bokhorst, C. L., Sumter, S. R., Westenberg, P. M. (2010): Social support from parents, friends, classmates, and teachers in children and adolescents aged 9 to 18 years: Who is perceived as most supportive? Social Development 19(2): 417-426. DOI: 10.1111/j.1467-9507.2009.00540.x

2. Dávid B., Szabó T., Lukács Á. (2017): A Keresztény Roma Szakkollégiumi Hálózat (KRSZH) hallgatóinak utánkövetéses vizsgálata 2011-2016. Zárótanulmány. Budapest

3. Eccles, J. S., Roesner, R. W. (2011): Schools as developmental contexts during adolescence. Journal of Research on Adolescence 21(1): 225-241. DOI: 10.1111/j.1532-7795.2010.00725.x 
4. Forray R. K. (2013): Cigány egészség, cigány betegség. Mitől betegebbek? Educatio (22) 2: 177-186.

5. Hüse L., Pénzes M. (2015): Egészség, telepi körülmények között - kutatási öszszegző. Evangélikus Roma Szakkollégium, Nyíregyháza.

6. Kósa Zs. (2006): Telepszerü körülmények között élők egészségfelmérése. Egyetemi doktori $(\mathrm{PhD})$ értekezés. Debreceni Egyetem Orvos- és Egészségtudományi Centrum Népegészségügyi Iskola

7. Schaefer, D. R., Haas, S. A., Bishop, N. J. (2012): A dynamic model of US adolescents' smoking and friendship networks. American Journal of Public Health 102(6): 12-18. DOI: 10.2105/AJPH.2012.300705

8. Sivandani, A., Koohbanani, S. E., Vahidi, T. (2013): The Relation Between Social Support and Self-efficacy with Academic Achievement and School Satisfaction among Female Junior High School Students in Birjand. Procedia 84: 668-673. DOI: 10.1016/j.sbspro.2013.06.623

9. Solymosy J. B. (2007): A romák egészségi állapota Magyarországon. In: Egyenlőség, egészség és a roma/cigány közösség. Madrid, Fundación Secretariado Gitano. 28-55.

10. Székely L, Szabó A (szerk.) (2017): Magyar Ifjúság Kutatás 2016. Új Nemzedék Központ Nonprofit Kft.

11. Taylor, R. D., Budescu, M., Gebre, A. (2014): Family financial pressure and maternal and adolescent socioemotional adjustment: Moderating effects of kin social support in low income African American families. Journal of Child and Family Studies 23(2): 242-254. DOI 10.1007/s10826-012-9688-8

12. Tjora, T., Hetland, J., Aarø, L. E., Øverland, S. (2011): Distal and proximal family predictors of adolescents' smoking initiation and development: A longitudinal latent curve model analysis. BMC Public Health 11 (1):911. DOI: 10.1186/1471-2458-11-911

13. Viner, R. M., Ozer, E. M., Denny, S., Marmot, M., Resnick, M., Fatusi, A. Currie, C. (2012): Adolescence and the social determinants of health. The Lancet 379(9826): 1641-1652. DOI: 10.1016/S0140-6736(12)60149-4.

14. White, R., Renk, K. (2012): Externalizing behaviour problems during adolescence: An ecological perspective. Journal of Child and Family Studies 21: 158-171. DOI 10.1007/s10826-011-9459-y

\section{Internetes hivatkozások}

1. 2019. évi országjelentés - Magyarország. A Bizottság közleménye az európai parlamentnek, az európai tanácsnak, a tanácsnak, az európai központi banknak és az eurócsoportnak. https://ec.europa.eu/info/sites/info/files/file_import/2019european-semester-country-report-hungary_hu.pdf (Utoljára látogatva: 2019.05.19)

2. Munkaerőpiaci helyzetkép, 2014-2018. KSH. http://www.ksh.hu/docs/hun/xftp/idoszaki/munkerohelyz/munkerohelyz17.pdf (Utoljára látogatva: 2019.05.19) 